Supporting Information

\title{
One-Step Low-Temperature Reduction of Sulfur Dioxide to Elemental Sulfur by Plasma-Enhanced Catalysis
}

Mohammad S. AlQahtani1 ${ }^{1,2}$, Sean D. Knecht ${ }^{3}$, Xiaoxing Wang ${ }^{1}$, Sven G. Bilén ${ }^{3,4}$, and Chunshan Song ${ }^{1,2 *}$

${ }^{1}$ Clean Fuels \& Catalysis Program, EMS Energy Institute, Department of Energy and Mineral Engineering, The Pennsylvania State University, University Park, PA, 16802 (USA)

${ }^{2}$ Department of Chemical Engineering, The Pennsylvania State University, University Park, PA, 16802 (USA)

${ }^{3}$ School of Engineering Design, Technology, and Professional Programs, The Pennsylvania State University, University Park, PA, 16802 (USA)

${ }^{4}$ School of Electrical Engineering and Computer Science, The Pennsylvania State University, University Park, $P A, 16802$ (USA)

Corresponding author: (*) csong@psu.edu 


\section{Experimental:}

The reactions were carried out in a coaxial double dielectric barrier discharge (DBD) reactor at atmospheric pressure. The reactor consists of a pair of glass tubes, inner quartz tube $(13 \mathrm{~mm} \mathrm{O.D.} \times 10$ $\mathrm{mm} \mathrm{I.D)} \mathrm{and} \mathrm{outer} \mathrm{borosilicate} \mathrm{tube} \mathrm{(22} \mathrm{mm} \mathrm{O.D.} \times 18 \mathrm{~mm} \mathrm{I.D).} \mathrm{The} \mathrm{high} \mathrm{voltage} \mathrm{electrode} \mathrm{is} \mathrm{a} \mathrm{9-mm-}$ diameter copper rod placed inside the inner tube, whereas the grounding electrode is a copper sheet wrapping the outer tube. The discharge gap is approximately $2.5 \mathrm{~mm}$ across and $50 \mathrm{~mm}$ in length. The feed flow rate was controlled by mass flow controllers and kept at $100 \mathrm{ml} / \mathrm{min}$ in all experiments. The reactor was connected to an alternating current (AC) high voltage power supply (Trek Inc. model 30/20), and a waveform generator (Agilent $33220 \mathrm{~A}$ ), with a maximum voltage of $30 \mathrm{kV}$ and variable frequency. In this work the voltage was varied, but the frequency was fixed at $2 \mathrm{kHz}$. The applied voltage and voltage on an external capacitor $(10 \mathrm{nF})$ were recorded by a two-channel digital oscilloscope (Tektronix, TBS 1052B). The plasma power was calculated using the Lissajous method.

The reactor temperature was $150^{\circ} \mathrm{C}$ to ensure that the produced sulfur can exit the reaction zone in a liquid and/or vapor (sulfur sublime) form and did not deposit on the catalyst. Three different modes of operation were investigated: catalysis alone, plasma alone, and plasma catalysis. No reaction was observed in catalysis-alone mode (at $150{ }^{\circ} \mathrm{C}$ ). The amount of catalyst used was approximately $2.8 \mathrm{~g}$ (10-14 mesh). Packing any material (inert or catalytic) reduces the discharge volume as well as residence time. Thus, in plasma-alone mode, two variations were considered: a totally empty reactor and a reactor packed with crushed pyrex glass (10-14 mesh, similar to a catalyst). This allows us to identify plasma performance, dielectric particle size effects, and finally plasma-catalyst coupling synergy.

The products were analyzed using an online micro-gas chromatograph (GC) (Agilent 3000A) equipped with thermal conductivity detectors (TCD) and two columns: a Molecular Sieve column to separate inert gases $\left(\mathrm{H}_{2}, \mathrm{O}_{2}, \mathrm{~N}_{2}, \mathrm{CH}_{4}\right.$, and $\left.\mathrm{CO}\right)$ and a Plot $\mathrm{Q}$ column to separate sour gases and light hydrocarbons $\left(\mathrm{CO}_{2}, \mathrm{H}_{2} \mathrm{~S}, \mathrm{SO}_{2}, \mathrm{COS}, \mathrm{CS}_{2}\right.$, and $\left.\mathrm{C}_{2}+\right)$.

The reactor is placed in an electric furnace to control the temperature. The plasma discharge is an energy source that can also cause a temperature increase. Thus, an infrared camera was used to measure the temperature of reactor from outside (grounding electrode temperature) before and after the reaction. Typically, a maximum of $30^{\circ} \mathrm{C}$ increase was observed; the grounding electrode is bombarded by highly energetic electrons and its temperature is expected to increase; however, the bulk of the gas should have lower temperatures. To ensure that there is no contribution from thermal catalysis due to this temperature rise, the catalysis operation mode was repeated at $200{ }^{\circ} \mathrm{C}$ and no reaction was observed. The sulfur balance is estimated to be $90-95 \%$ in all experiments. 
A.

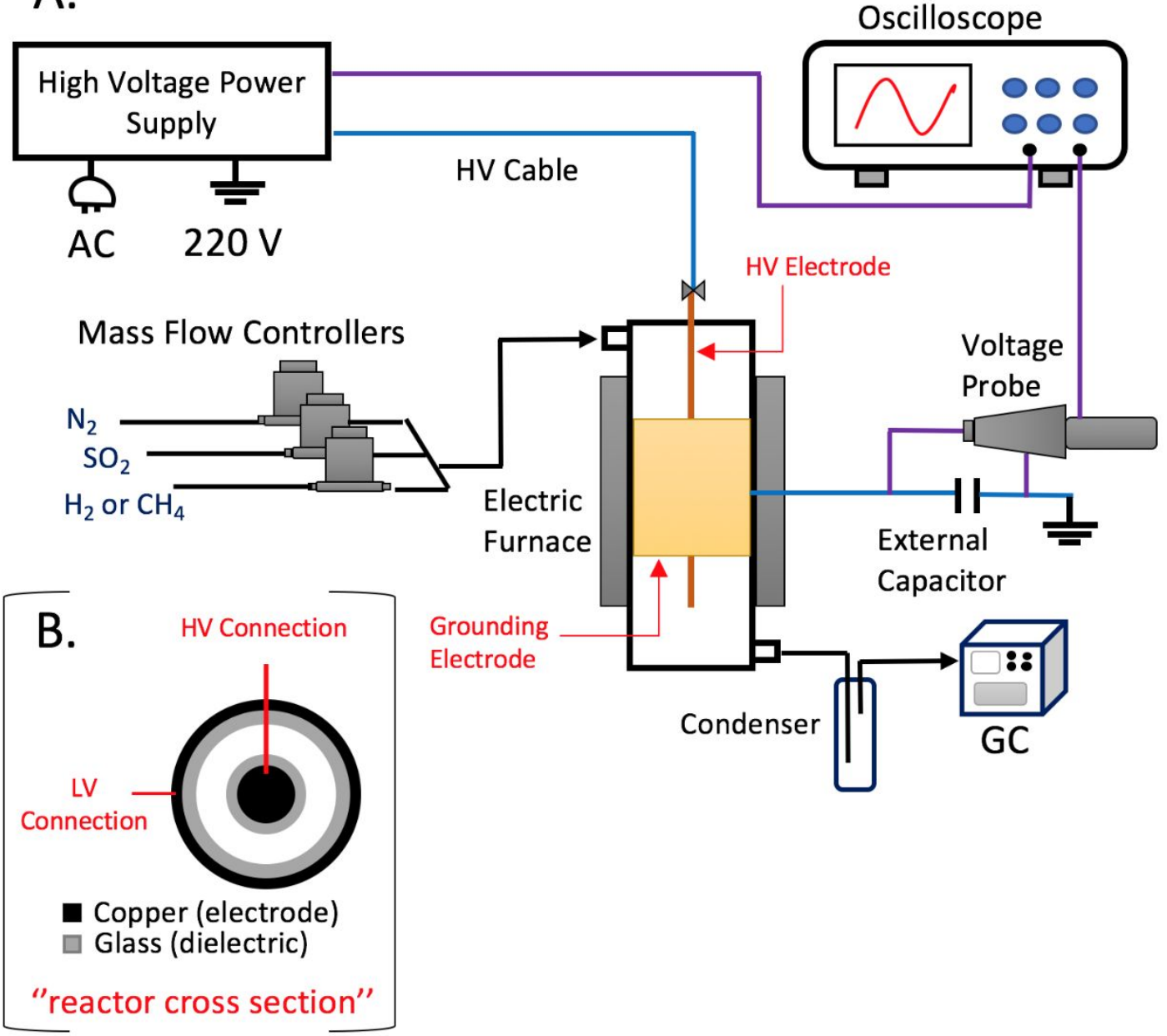

Scheme S1: A. Schematic diagram of experimental setup. B. Reactor cross section.

The conversion of a specie $(i)$ is defined as:

$X_{i}(\%)=\frac{\text { moles of } i \text { converted }}{\text { moles of initial } i} \times 100$

where $i$ could be $\left(\mathrm{SO}_{2}, \mathrm{H}_{2}\right.$, or $\left.\mathrm{CH}_{4}\right)$.

The selectivity of products is calculated by:

$S_{\text {sulfur }}(\%)=\left(1-\frac{\text { moles of } \mathrm{H}_{2} \mathrm{~S} \text { and } / \text { or CoS produced }}{\text { moles of } \mathrm{SO}_{2} \text { converted }}\right) \times 100$

$S_{\mathrm{H}_{2}}(\%)=\frac{\text { moles of } \mathrm{H}_{2} \text { produced }}{2 \times \text { moles of } \mathrm{CH}_{4} \text { converted }} \times 100$

$S_{\mathrm{CO}}(\%)=\frac{\text { moles of } \mathrm{CO} \text { produced }}{\text { moles of } \mathrm{CH}_{4} \text { converted }} \times 100$

$S_{\mathrm{C}_{y} H_{z}}(\%)=\frac{y \text { moles of } \mathrm{C}_{y} \mathrm{H}_{z} \text { produced }}{\text { moles of } \mathrm{CH}_{4} \text { converted }} \times 100$ 


\section{Catalyst preparation}

All catalysts were prepared by wet impregnation of aqueous solution onto $\gamma-\mathrm{Al}_{2} \mathrm{O}_{3}$ (UOP Versal Alumina VGL-15). Metal salts $\left(\mathrm{Fe}\left(\mathrm{NO}_{3}\right)_{3} \cdot 9 \mathrm{H}_{2} \mathrm{O}\right.$ and $\mathrm{Zn}\left(\mathrm{NO}_{3}\right)_{2} \cdot 6 \mathrm{H}_{2} \mathrm{O}$, Sigma-Aldrich) were dissolved in distilled water (excess of water), then the support was added and stirred for $12 \mathrm{~h}$, at room temperature. After that, the solution was dried in air at $50^{\circ} \mathrm{C}$. The resulting solid lumps were crushed into powder form then dried at $120{ }^{\circ} \mathrm{C}$ under vacuum for $12 \mathrm{~h}$, and further calcined in air at $550{ }^{\circ} \mathrm{C}$ for $3 \mathrm{~h}$. The sulfidation of metal oxide was carried out at $400{ }^{\circ} \mathrm{C}$ under $80 \mathrm{ml} / \mathrm{min}$ flow of $5 \% \mathrm{H}_{2} \mathrm{~S}$ in $\mathrm{N}_{2}$ gas. Further sulfidation was carried out under plasma at $10 \mathrm{~W}$ and $150{ }^{\circ} \mathrm{C}$ for $1 \mathrm{~h}$. Metal loading was fixed at $10 \mathrm{wt} . \%$ for both $\mathrm{Fe}$ and $\mathrm{Zn}$.

\section{Catalyst characterization}

The alumina support acidity was evaluated by $\mathrm{NH}_{3}$ temperature-programed desorption $\left(\mathrm{NH}_{3}\right.$-TPD) using a Micromeritics Autochem 2910 instrument. The sample $(150 \mathrm{mg})$ was pretreated at $600{ }^{\circ} \mathrm{C}$ for $2 \mathrm{~h}$ in $\mathrm{He}$ flow $(30 \mathrm{ml} / \mathrm{min})$, then cooled to $120^{\circ} \mathrm{C}$. After that, the sample was saturated with $\mathrm{NH}_{3}$, and later purged with $\mathrm{He}(30 \mathrm{ml} / \mathrm{min})$ for $1 \mathrm{~h}$. Finally, the TPD profile was recorded while heating the sample from 120 to $600{ }^{\circ} \mathrm{C}$ at a heating rate of $10^{\circ} \mathrm{C} / \mathrm{min}$ in He flow.

$\mathrm{H}_{2}$ temperature-programmed reduction was performed using the same instrument as $\mathrm{NH}_{3}-\mathrm{TPD}$. The sample $(100 \mathrm{mg})$ was pretreated at $550{ }^{\circ} \mathrm{C}$ for $1 \mathrm{~h}$ in Ar flow $(25 \mathrm{ml} / \mathrm{min})$, then cooled to $50^{\circ} \mathrm{C}$. After that, the sample was exposed to $10 \% \mathrm{H}_{2} / \mathrm{Ar}$ mixture while heating from 50 to $600{ }^{\circ} \mathrm{C}$ at a rate of $10{ }^{\circ} \mathrm{C} / \mathrm{min}$ to obtain the TPR profile.

$\mathrm{N}_{2}$ physisorption was conducted at $-196^{\circ} \mathrm{C}$ using a Micromeritics TriStar II analyzer. All calcined catalysts and support were degassed at $250^{\circ} \mathrm{C}$ for $12 \mathrm{~h}$ prior to $\mathrm{N}_{2}$ physisorption measurements. The surface area was calculated according to the Brunauer-Emmett-Teller (BET) method, whereas a Barrett-JoynerHalenda (BJH) model was used to obtain pore volume and average diameter. Fe- and Zn-supported catalysts exhibit very similar physical surface properties as reported in Table S1.

XRD patterns of sulfided catalysts were collected using a PANalytical Empyrean X-ray Diffractometer with $\mathrm{Cu} \mathrm{K} \mathrm{K}_{\alpha}(\lambda=0.154059 \mathrm{~nm})$ radiation.

Field-emission scanning electron microscope (FESEM) images of fresh $\gamma-\mathrm{Al}_{2} \mathrm{O}_{3}$ and iron sulfide catalyst were obtained using an Apreo FESEM instrument. The samples were sputtered with $10 \mathrm{~nm}$ of iridium to minimize charging effects.

High resolution TEM, high angle annular dark field (HAADF), and elemental mapping images of fresh iron sulfide catalyst were acquired using Talos F200X instrument equipped with XFEG source and SuperX EDS.

Diffuse reflectance infrared Fourier transform spectroscopy (DRIFTS) was performed using NICOLET 6700 instrument with a high temperature cell. 


\section{Result and discussion}

Packing any material (inert or catalytic) in the discharge zone could impose many physical changes, hence altering the chemical reactions. It reduces gap voids (discharge volume), shortens residence time, and might changes discharge mode from filamentary to spatially-limited microdischarges and surface discharge. As shown in Figure S1, the shape of the Lissajous figures are almost the same for different operation modes, indicating that no major physical changes to the discharge mode were observed.

In our reaction system, no $\mathrm{N}$-containing byproducts were produced. However, $\mathrm{N}_{2}$ excited species, specially $\mathrm{N}_{2}(A)$ which is the first electronically excited state of nitrogen (metastable nitrogen), can act as charge/energy carrier. To confirm that $\mathrm{N}_{2}$ does not chemically react or involve in the reactions as an intermediate, we have used argon as the carrier gas in 3 addition experiments: empty reactor, $\mathrm{Al}_{2} \mathrm{O}_{3}$, and $\mathrm{FeS} / \mathrm{Al}_{2} \mathrm{O}_{3}$ packed reactors for the $\mathrm{H}_{2} / \mathrm{SO}_{2}$ reaction. The result is shown in Figure $\mathrm{S} 2 . \mathrm{SO}_{2}$ reduction took place regardless of the balance gas, and as expected the conversions were higher when using $\mathrm{Ar}$ as the balance gas. Unlike $\mathrm{N}_{2}$, argon is monoatomic molecule, thus no energy loss due to weak rotational and vibrational excitation.

Catalyst properties were characterized by $\mathrm{N}_{2}$-physisorption, $\mathrm{NH}_{3}-\mathrm{TPD}, \mathrm{H}_{2}-\mathrm{TPR}$, and XRD to gain some insights about their catalytic performance. The alumina support has a surface area of $158 \mathrm{~m}^{2} / \mathrm{g}$ and many acid sites that could contribute to $\mathrm{SO}_{2}$ adsorption (Figure S8) $\mathrm{H}_{2}$-TPR results revealed that the $\mathrm{Fe}$ catalyst is easily reduced to its metallic phase opposite to zinc as presented in Figure S9.

Discharge energy could transform into heat; hence, it is important to confirm whether there is a contribution from thermal catalysis or not. As shown in Figure S14, via IR camera, we observed a temperature increase in the first $15 \mathrm{~min}$ from room temperature to around $60{ }^{\circ} \mathrm{C}$, then the temperature remained approximately constant. Such a small change would not activate the catalysts thermally, as they are inactive even at $200^{\circ} \mathrm{C}$.

The produced elemental sulfur can be clearly seen in Figure S15. Solid sulfur was deposited on the glass tubes wall downstream the reaction zone. The XRD pattern of the produced sulfur is shown in Figure S16, which corresponds to $\mathrm{S}_{8}$.

Since both $\mathrm{SO}_{2}$ and $\mathrm{H}_{2} \mathrm{~S}$ coexist in our system, we have studied the Claus reaction under plasma conditions. We confirmed that plasma-generated species can indeed initiate the Claus homogenousreaction as shown in Figure S3.

$\mathrm{SO}_{2}$ and co-reactant $\left(\mathrm{H}_{2}\right.$ or $\left.\mathrm{CH}_{4}\right)$ conversions are presented in Figures $\mathrm{S} 4$ and $\mathrm{S} 5$; all experimental conditions were kept the same. Figure $\mathrm{S} 7$ shows $\mathrm{SO}_{2} / \mathrm{H}_{2}$ conversions over iron sulfide catalyst as a function of reaction time. The typical procedure that we use is as follow: 1) feed gas is introduced to the catalyst bed, 2) Online GC analysis is started to make sure there is no thermal catalytic reaction. 3) Plasma is switch on. So, $\mathrm{t}=0$ in Figure $\mathrm{S} 7$ marks the plasma initiation.

The vibrationally-excited $\mathrm{H}_{2}, \mathrm{CH}_{4}$, and $\mathrm{SO}_{2}$ molecules could promote dissociative chemisorption at the catalytic surfaces, leading to higher activation at low temperatures; either via plasma-surface activation (Table S4) or plasma-phase activation (Table S5). 

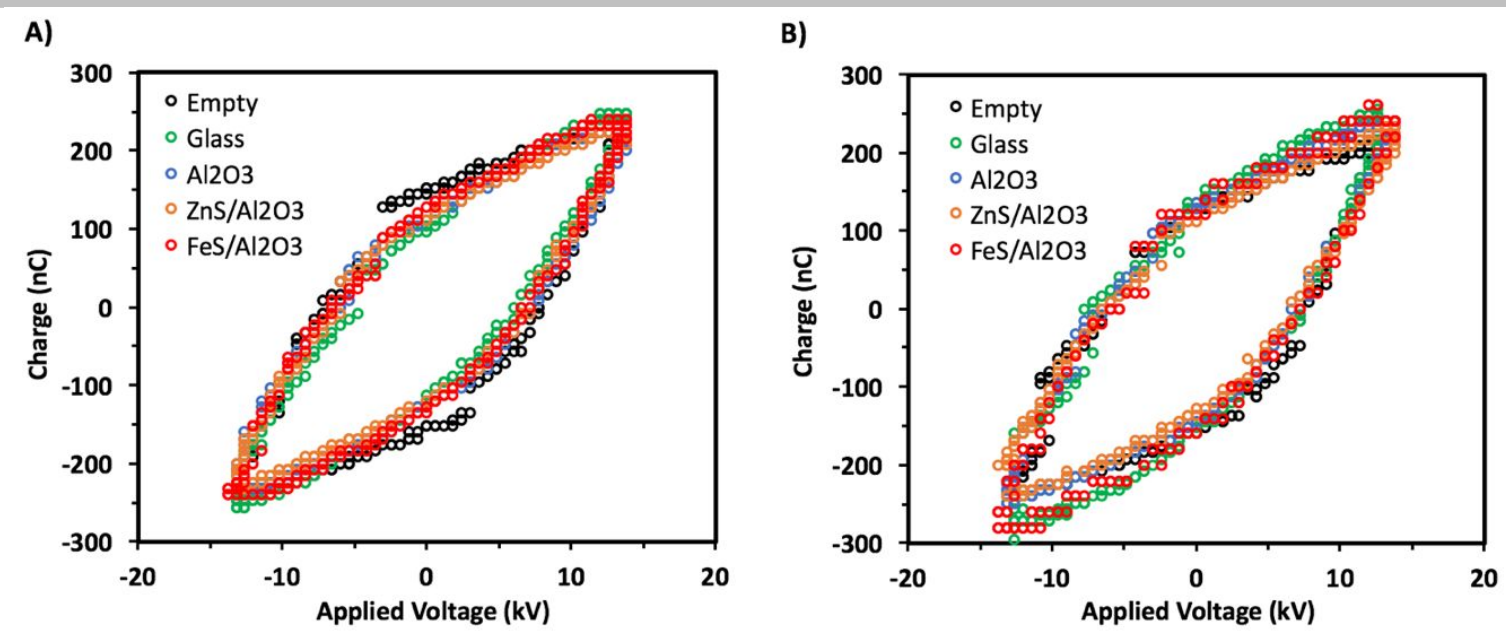

Figure S1: Lissajous figures of the different modes of operation for A) $\mathrm{H}_{2} / \mathrm{SO}_{2}$ and B) $\mathrm{CH}_{4} / \mathrm{SO}_{2}$ reactions at discharge power of $10 \pm 0.5 \mathrm{~W}$.

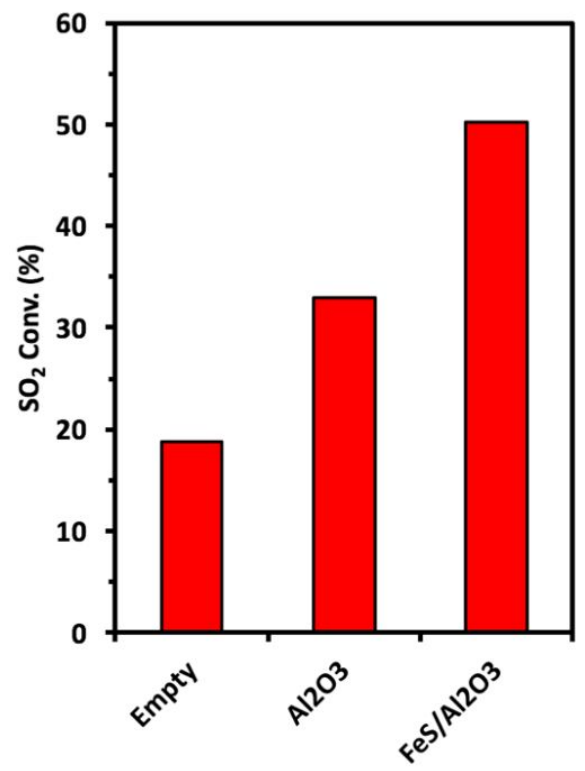

Figure S2: $\mathrm{SO}_{2}$ conversion when using $\mathrm{Ar}$ as balance gas. Reaction conditions: $1 \% \mathrm{SO}_{2}, 4 \% \mathrm{H}_{2}$, Ar balance, flow rate $=100 \mathrm{~mL} \mathrm{~min}^{-1}$ at $150{ }^{\circ} \mathrm{C}, 1 \mathrm{~atm}$, and $10 \mathrm{~W}$ DBD plasma.

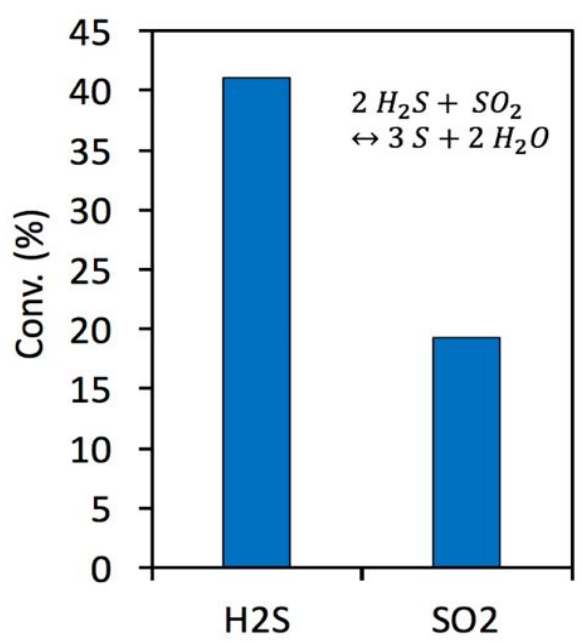

Figure S3: $\mathrm{H}_{2} \mathrm{~S}$ and $\mathrm{SO}_{2}$ conversions in plasma alone mode (empty reactor) at $150{ }^{\circ} \mathrm{C}, 6.5 \mathrm{~W}$. Feed composition: $2 \% \mathrm{H}_{2} \mathrm{~S}, 1 \% \mathrm{SO}_{2}, \mathrm{~N}_{2}$ balance, $100 \mathrm{ml} / \mathrm{min}$. 


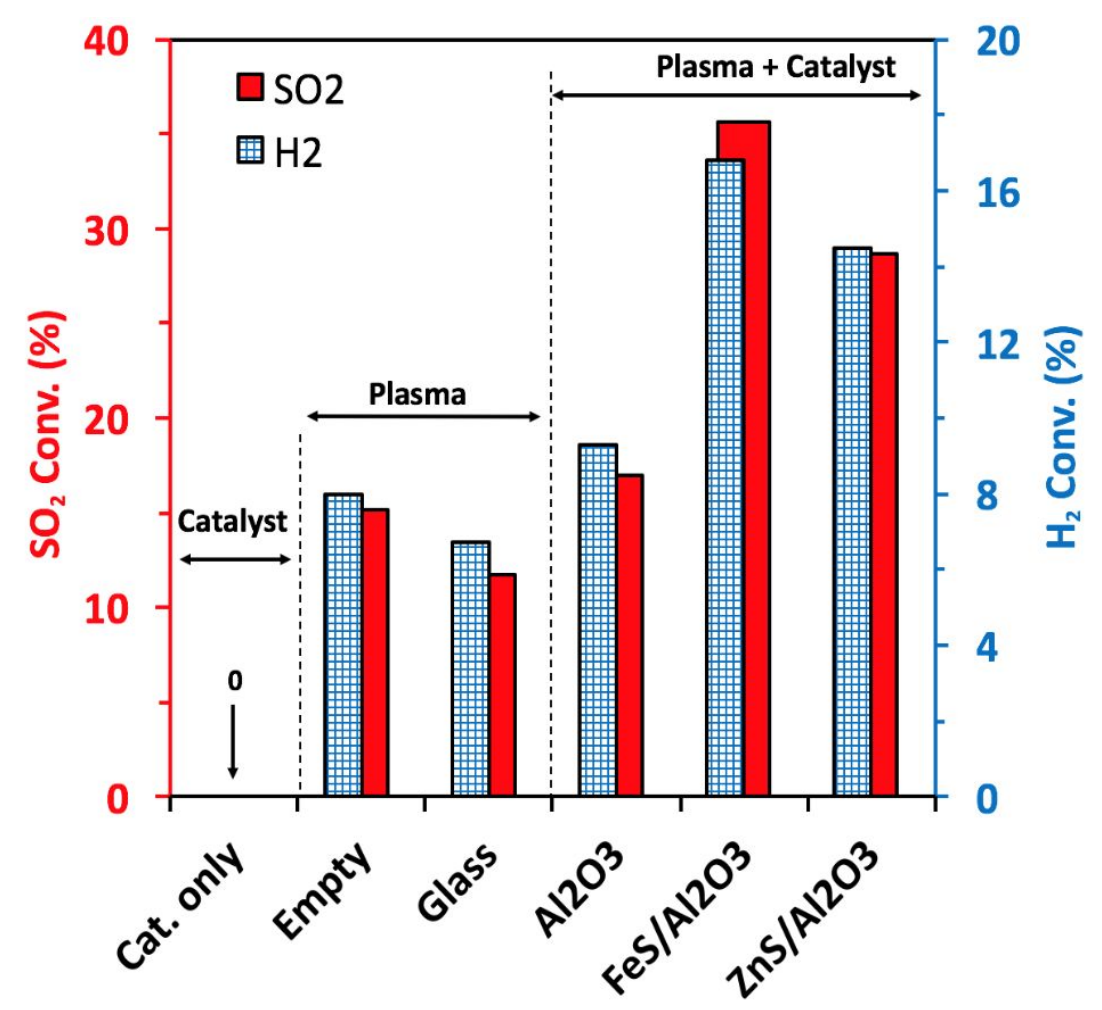

Figure S4: $\mathrm{H}_{2}$ and $\mathrm{SO}_{2}$ conversions with different packing materials at $150{ }^{\circ} \mathrm{C}, 10 \mathrm{~W}$. Feed composition: $4 \% \mathrm{H}_{2}$, $1 \% \mathrm{SO}_{2}, \mathrm{~N}_{2}$ balance, $100 \mathrm{ml} / \mathrm{min}$.

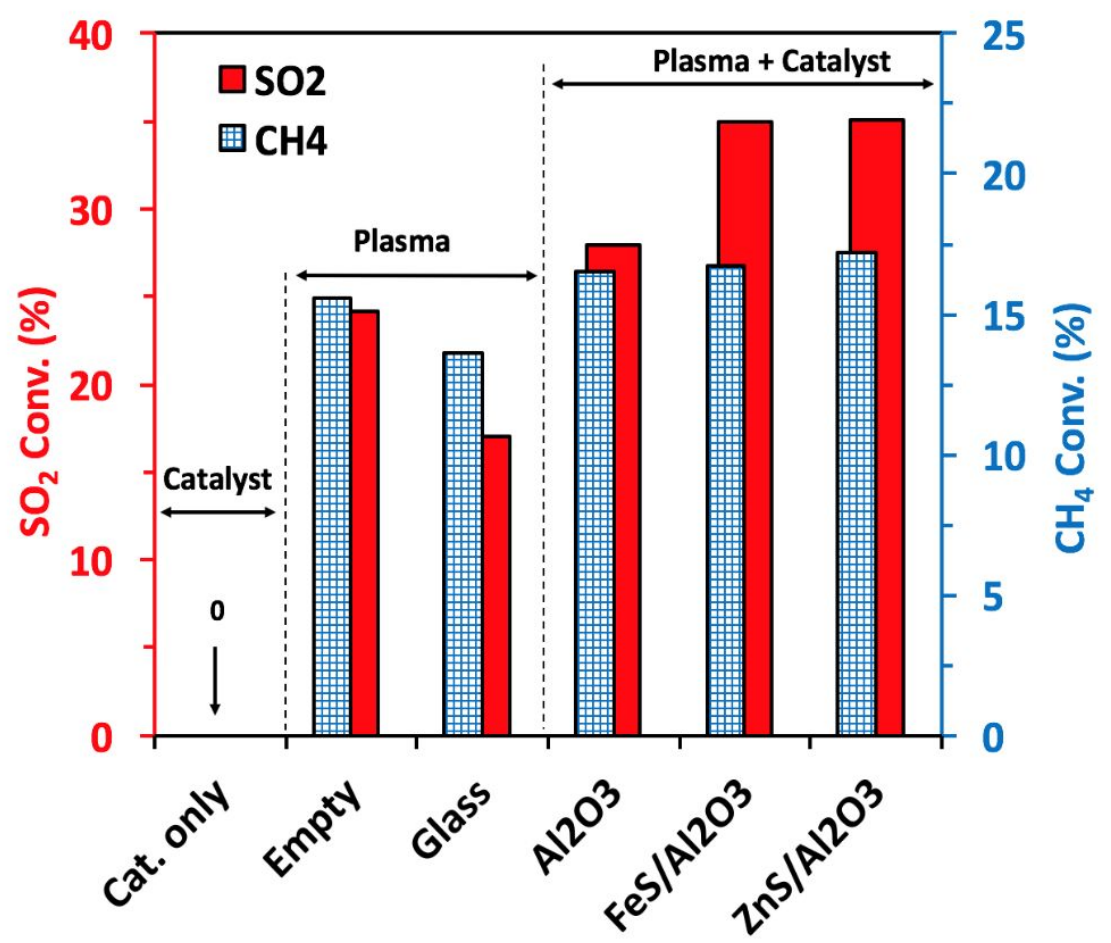

Figure S5: $\mathrm{CH}_{4}$ and $\mathrm{SO}_{2}$ conversions with different packing materials at $150{ }^{\circ} \mathrm{C}, 10 \mathrm{~W}$. Feed composition: $4 \%$ $\mathrm{CH}_{4}, 1 \% \mathrm{SO}_{2}, \mathrm{~N}_{2}$ balance, $100 \mathrm{ml} / \mathrm{min}$. 


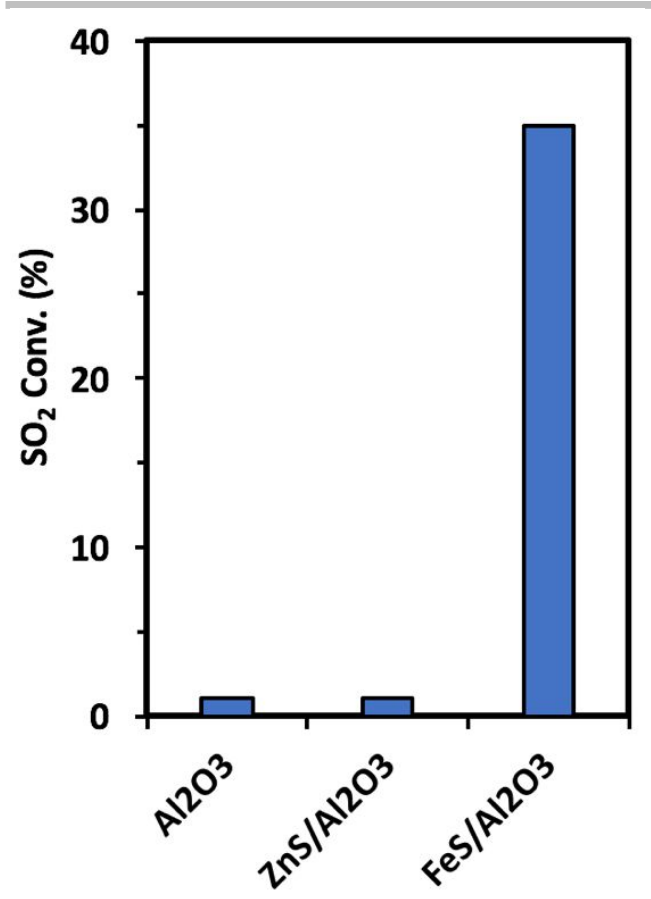

Figure S6: $\mathrm{SO}_{2}$ hydrogenation conversions over $\gamma-\mathrm{Al}_{2} \mathrm{O}_{3}, \mathrm{ZnS} / \gamma-\mathrm{Al}_{2} \mathrm{O}_{3}$, and $\mathrm{FeS} / \gamma-\mathrm{Al}_{2} \mathrm{O}_{3}$ at $400{ }^{\circ} \mathrm{C}$ (thermal catalysis, no plasma). Feed composition: $2 \% \mathrm{H}_{2}, 1 \% \mathrm{SO}_{2}, \mathrm{~N}_{2}$ balance, $55 \mathrm{ml} / \mathrm{min}$, catalyst mass is $200 \mathrm{mg}$.

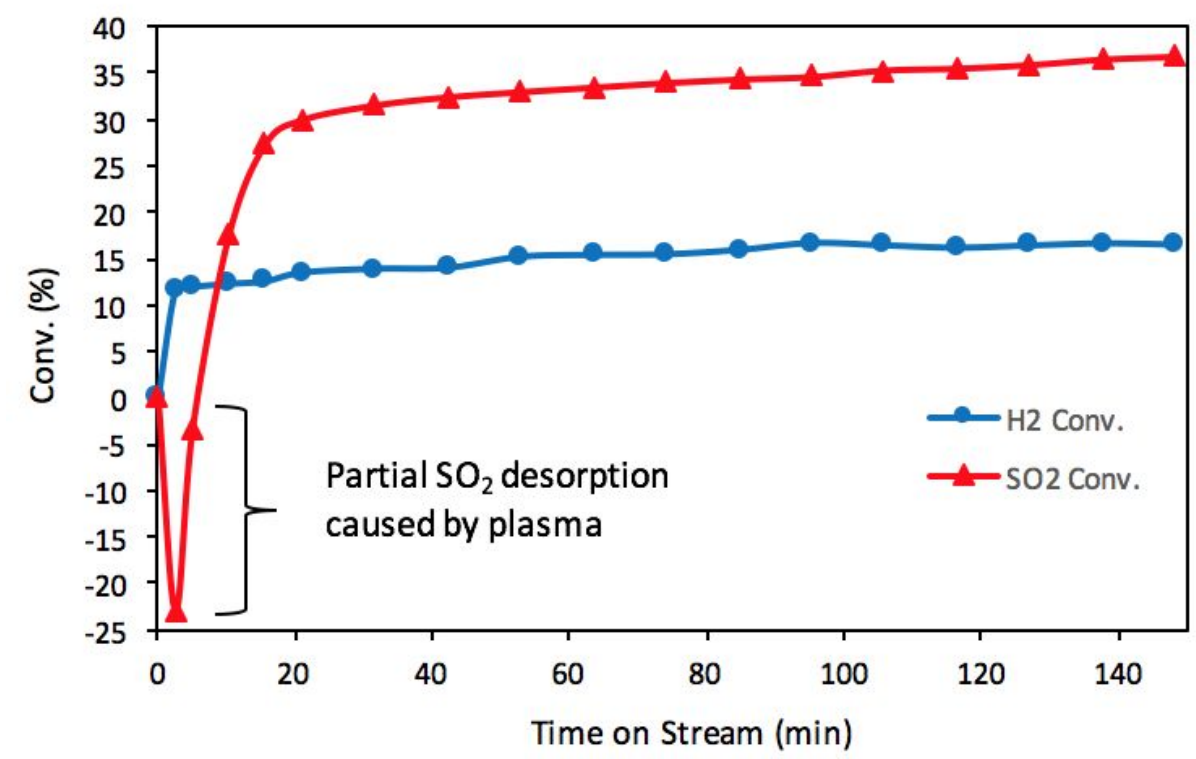

Figure S7: $\mathrm{H}_{2} / \mathrm{SO}_{2}$ conversion over $\mathrm{FeS}(10) / \gamma-\mathrm{Al}_{2} \mathrm{O}_{3}$ at $150{ }^{\circ} \mathrm{C}, 100 \mathrm{ml} / \mathrm{min}$, and $10 \mathrm{~W}$. 


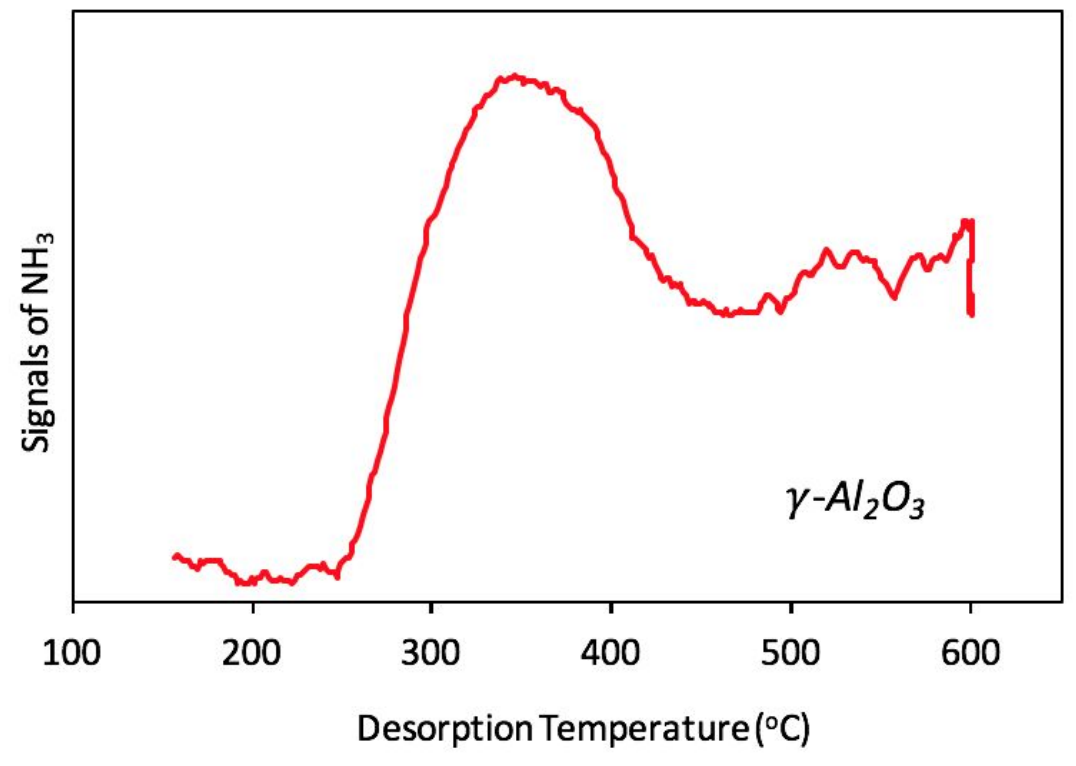

Figure S8: $\mathrm{NH}_{3}$ temperature-programmed desorption profile of $\gamma-\mathrm{Al}_{2} \mathrm{O}_{3}$ support.

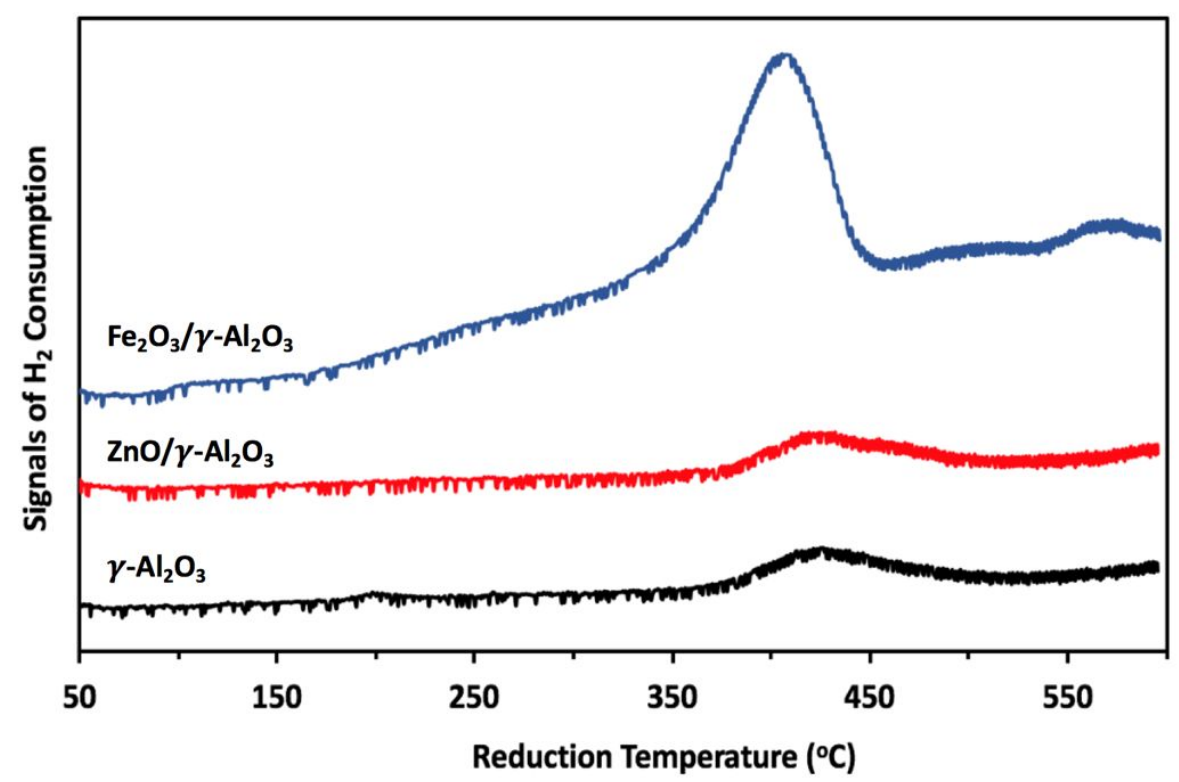

Figure S9: $\mathrm{H}_{2}$ temperature-programmed reduction profile of as-synthesized catalysts. 


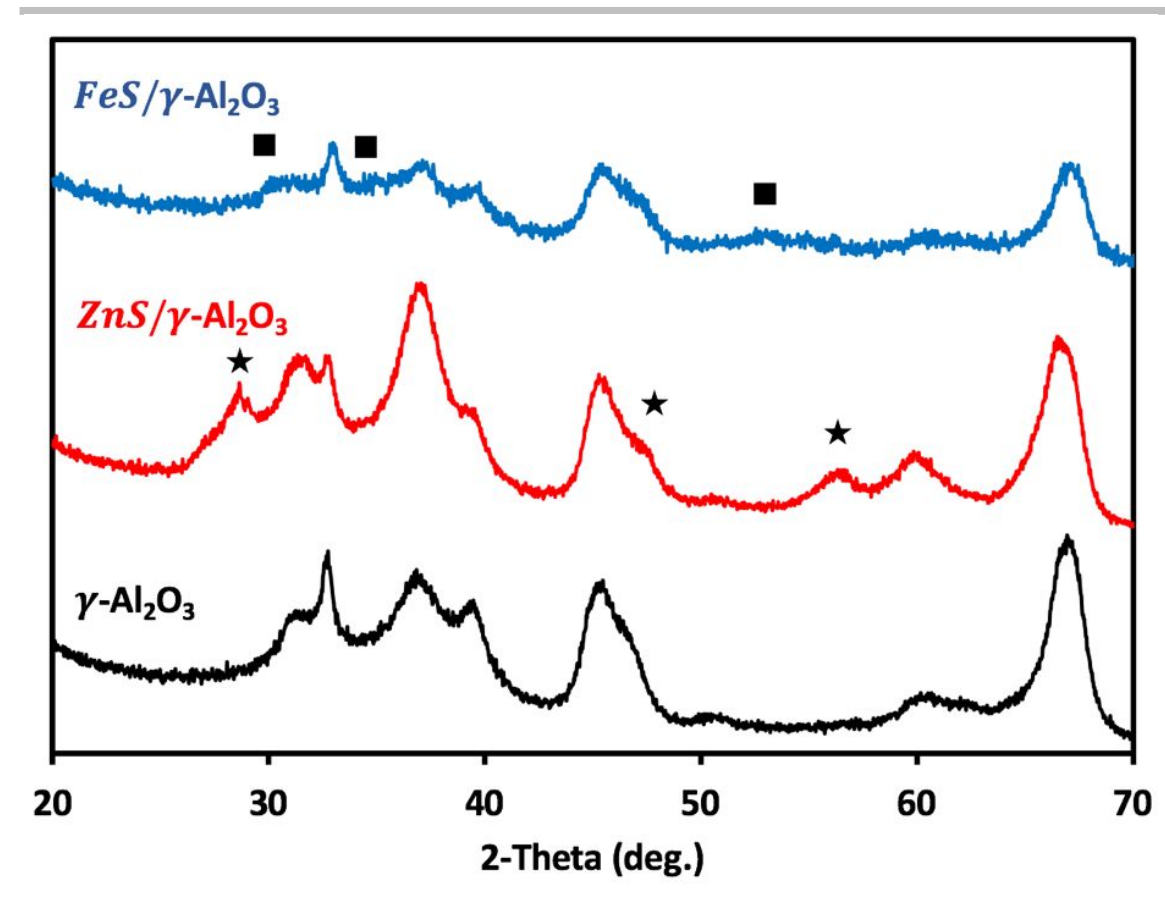

Figure S10: XRD patterns of sulfided catalysts ( $\star \mathrm{ZnS}$, $\left.\square \mathrm{FeS}_{2}\right)$.

Table S1: Physical properties of fresh catalysts

\begin{tabular}{|c|c|c|c|c|c|}
\hline Catalyst & $\begin{array}{c}\text { BET SA } \\
\left(\mathrm{m}^{2} / \mathrm{g}\right)\end{array}$ & $\begin{array}{c}\text { Micro pore } \\
\text { Area }\left(\mathrm{m}^{2} / \mathrm{g}\right)\end{array}$ & $\begin{array}{c}\text { Micro pore } \\
\text { Vol. }\left(\mathrm{cm}^{3} / \mathrm{g}\right)\end{array}$ & $\begin{array}{c}\text { Ads. Pore Vol. } \\
\left(\mathrm{cm}^{3} / \mathrm{g}\right)\end{array}$ & $\begin{array}{c}\text { Ads. Pore Size } \\
(\mathrm{nm})\end{array}$ \\
\hline$\gamma-\mathrm{Al}_{2} \mathrm{O}_{3}$ & 158 & 51 & 0.008 & 0.78 & 20.6 \\
\hline $\mathrm{FeS} / \gamma-\mathrm{Al}_{2} \mathrm{O}_{3}$ & 142 & 46 & 0.006 & 0.62 & 17.7 \\
\hline $\mathrm{ZnS} / \gamma-\mathrm{Al}_{2} \mathrm{O}_{3}$ & 143 & 40 & 0.006 & 0.69 & 18.0 \\
\hline
\end{tabular}


A.

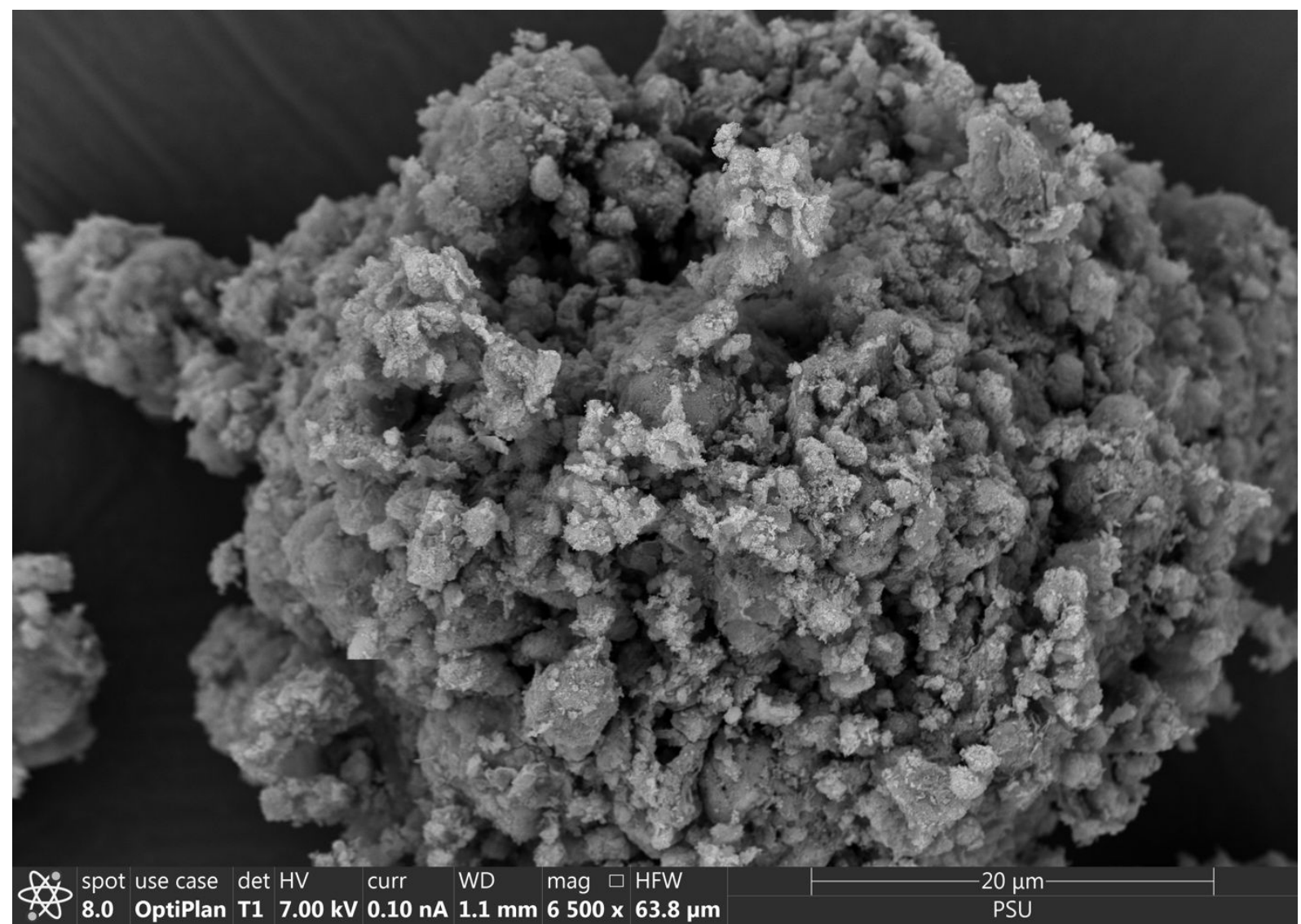

8.0 Optiplan T1 7.00 kV 0.10 nA 1.1 mm 6500 x $63.8 \mu \mathrm{m}$

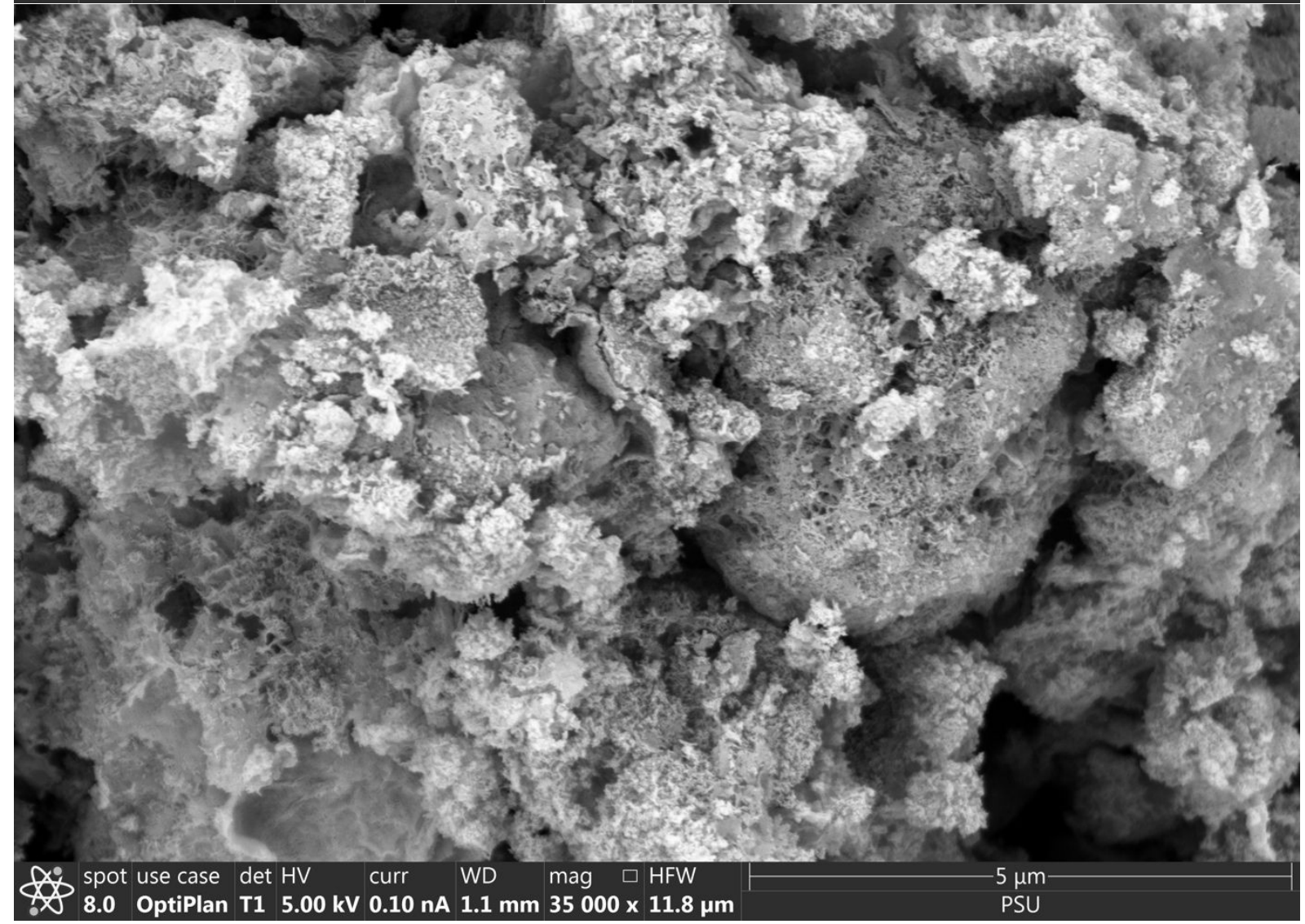


B.
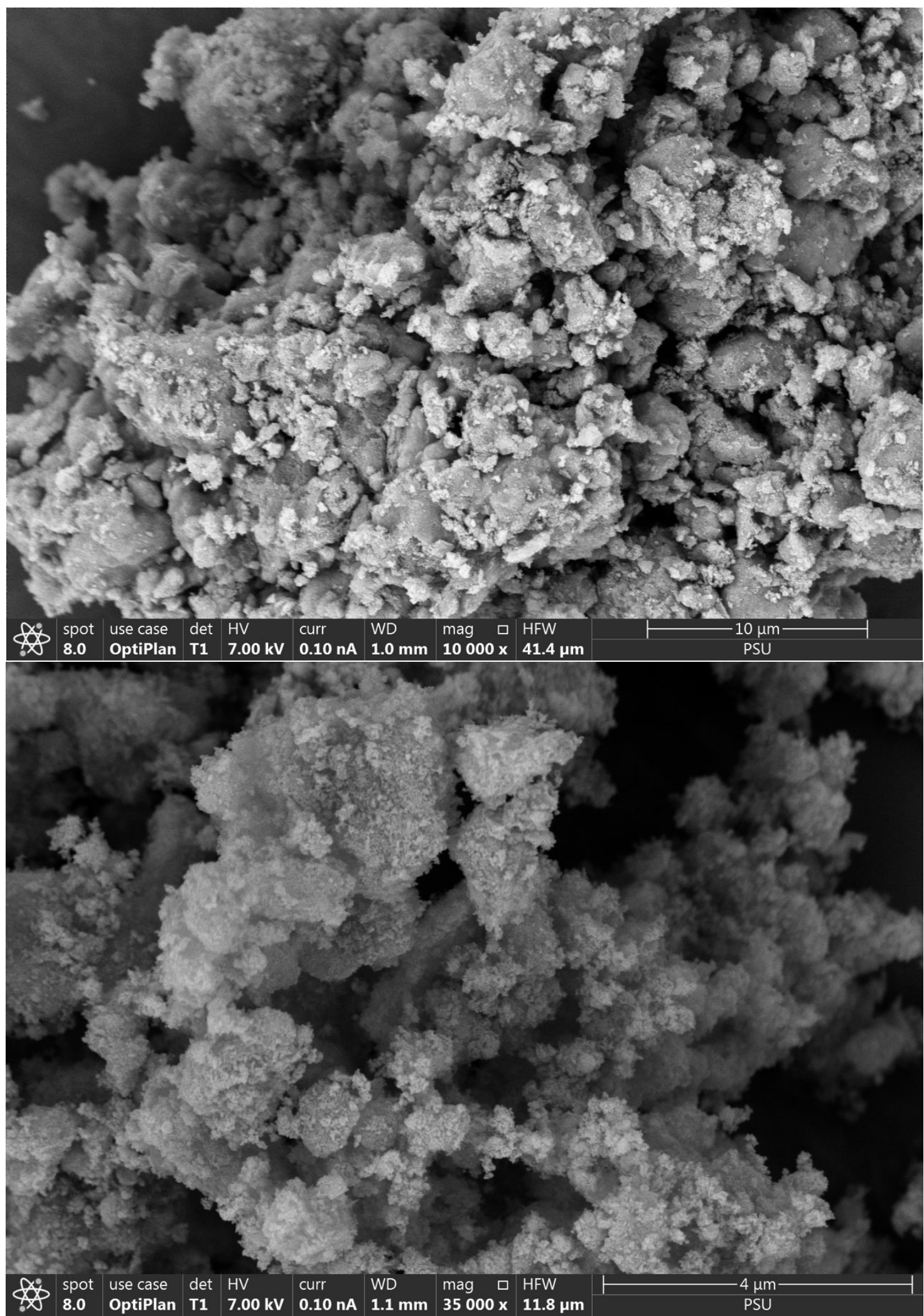

Figure S11: FESEM images, A) $\gamma-\mathrm{Al}_{2} \mathrm{O}_{3}$, B) Fresh iron sulfide catalyst. 


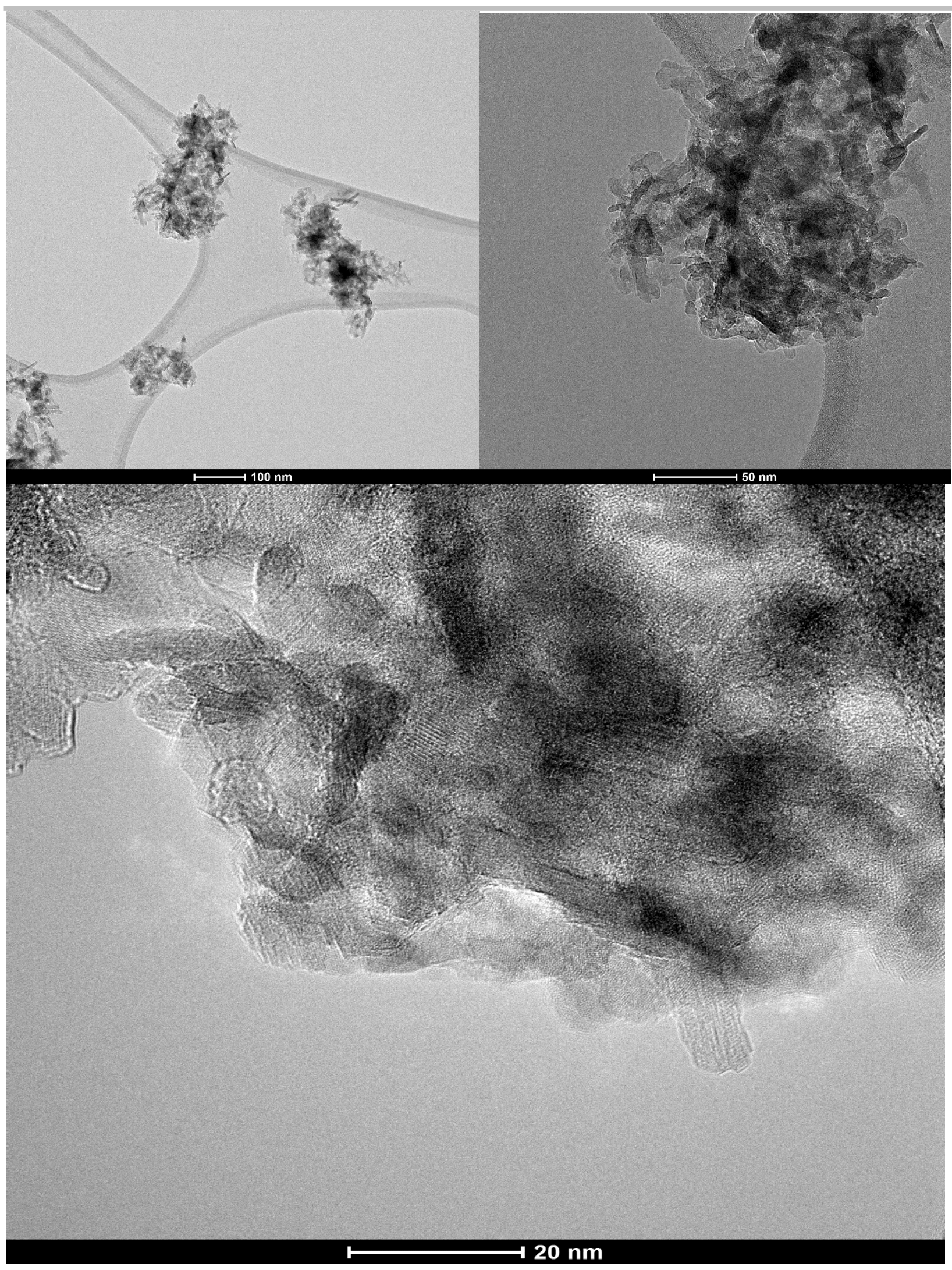

Figure S12: HRTEM images of iron sulfide catalyst used in this study. 


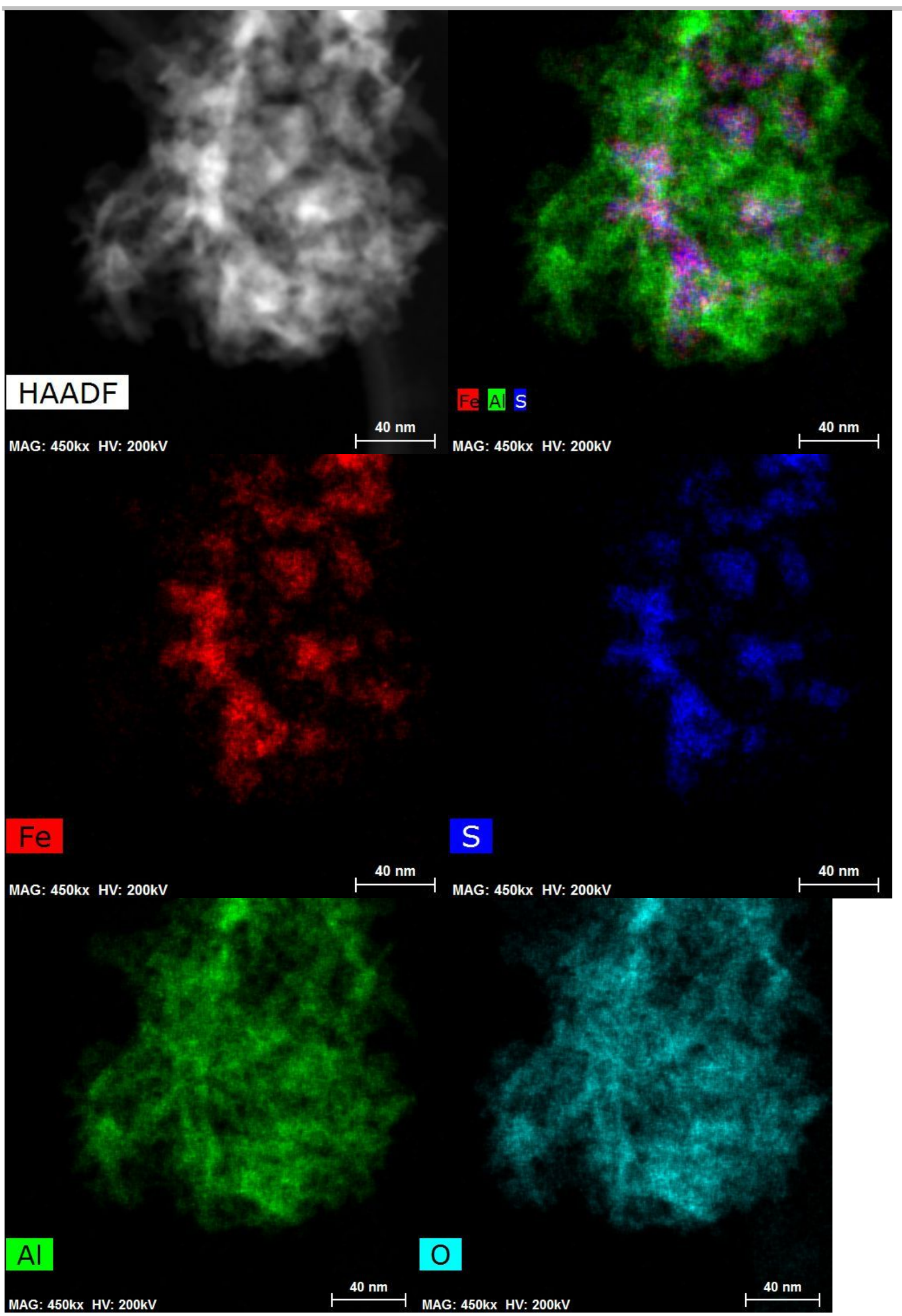

Figure S13: HAADF and EDS elemental mapping images of fresh iron sulfide catalyst. 
a)

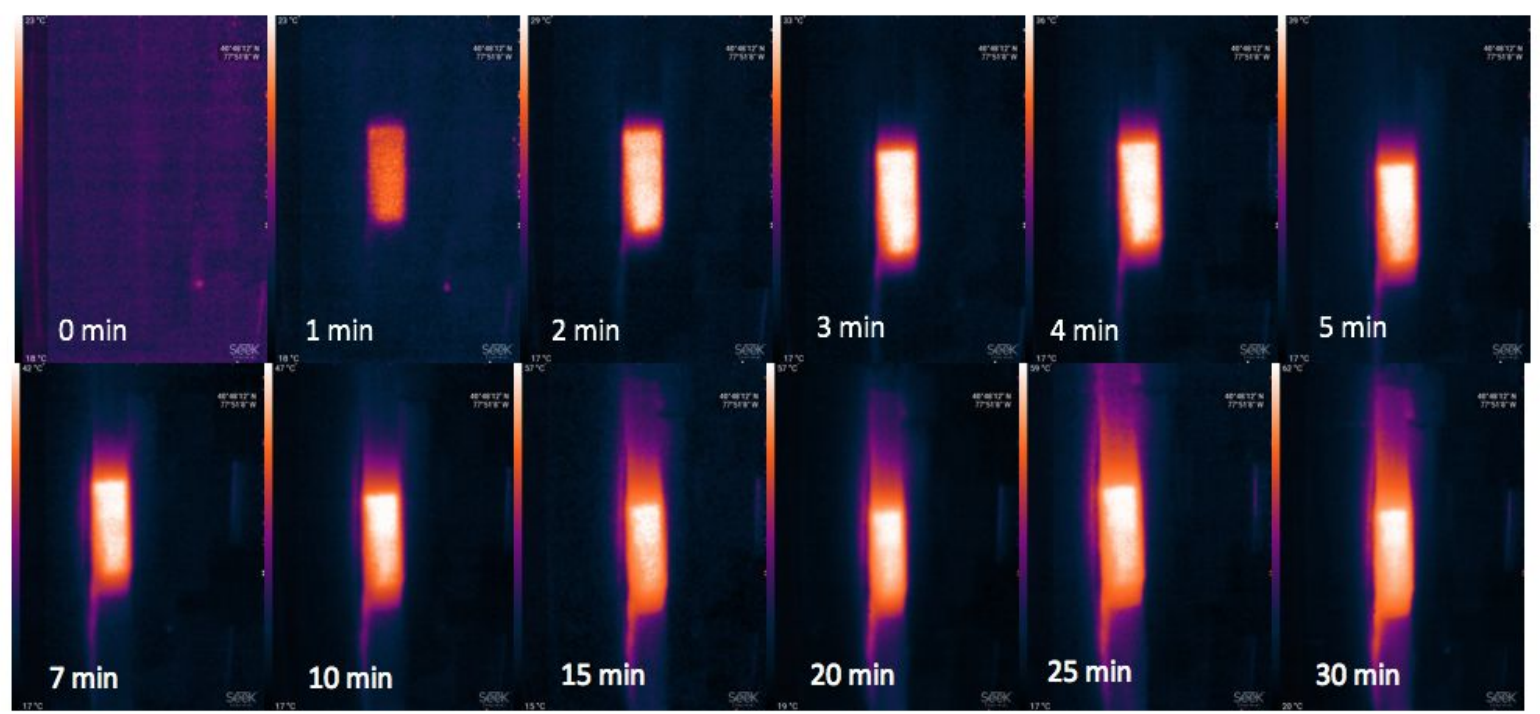

b)

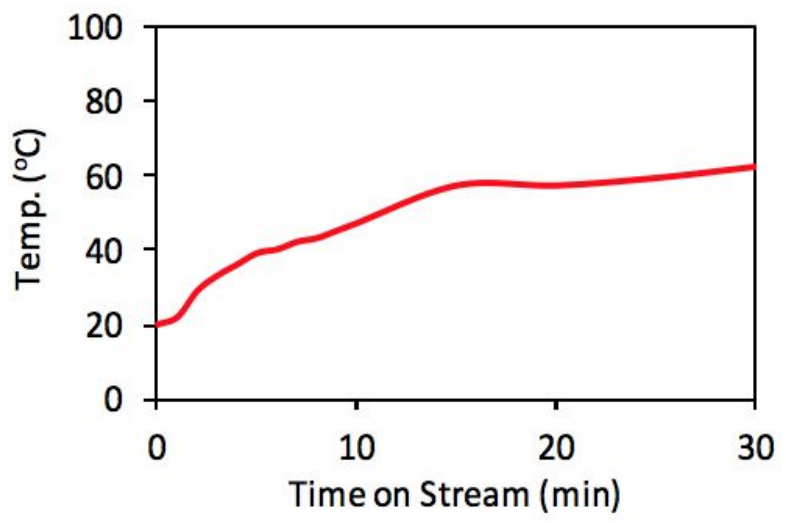

Figure S14: Grounding electrode temperature with time: a) actual IR camera photos, b) temperature vs. time plot $\left(\mathrm{H}_{2} / \mathrm{SO}_{2}=4,100 \mathrm{ml} / \mathrm{min}, 25.5 \mathrm{kV}, 2 \mathrm{kHz}\right.$ at $\left.\mathrm{RT}\right)$.

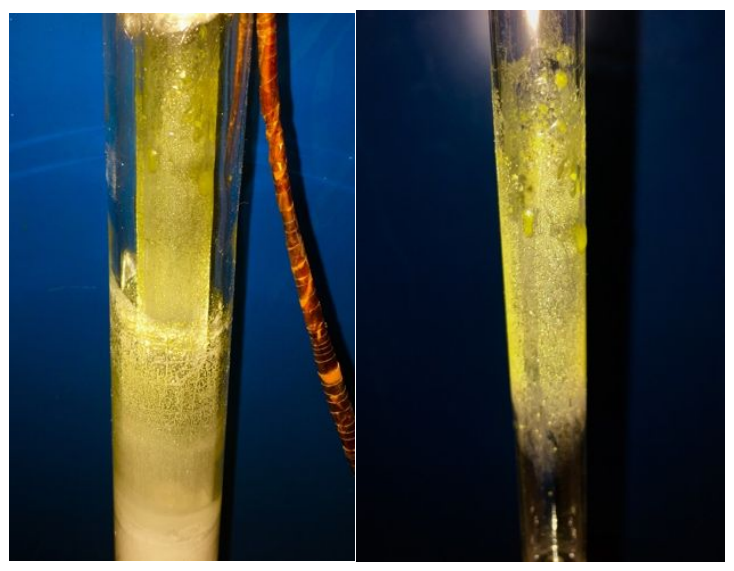

Figure S15: Sulfur deposition downstream the discharge zone: on the left a picture of the whole reactor, on the right a picture of inner tube. 


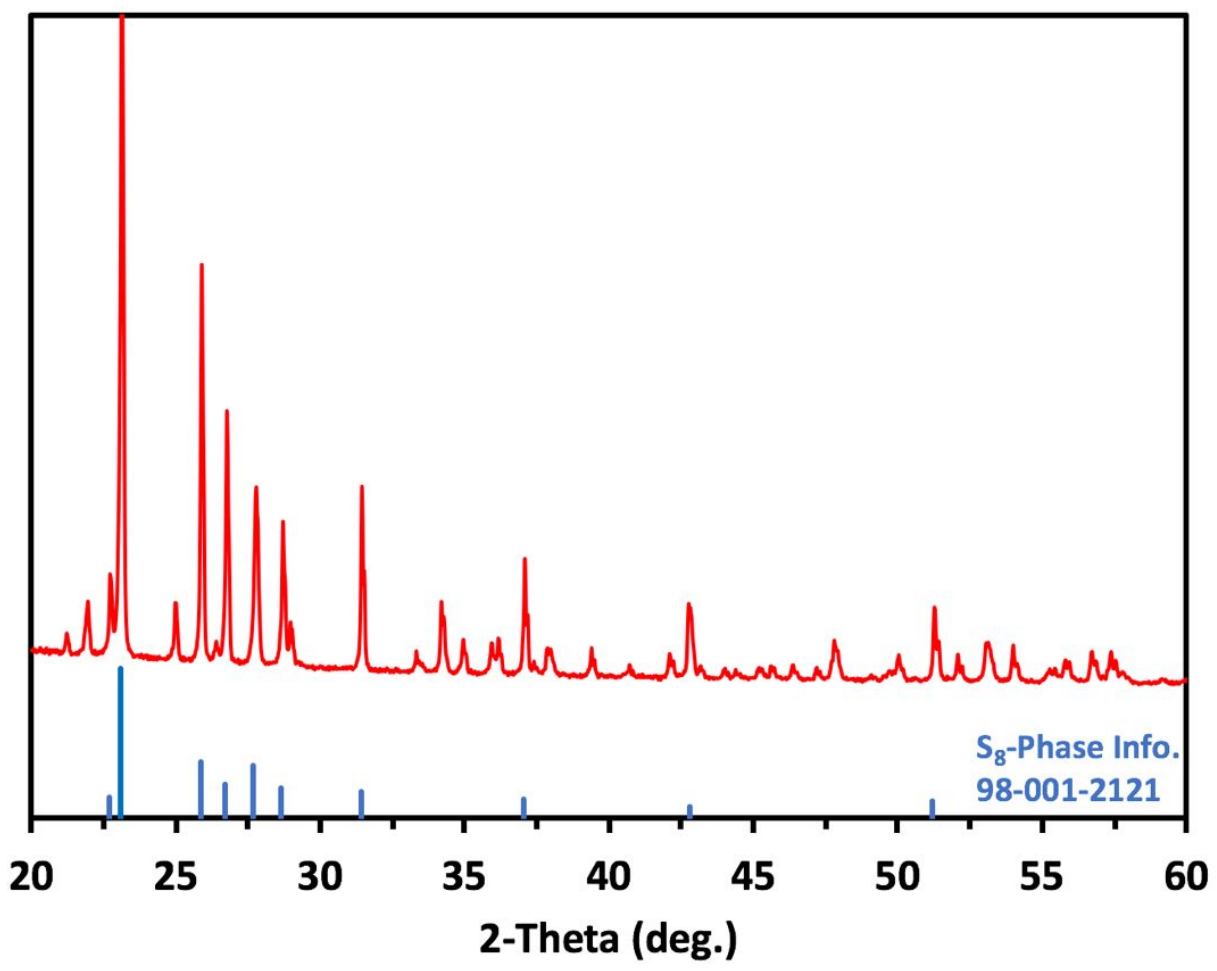

Figure S16: XRD pattern of the produced elemental sulfur.

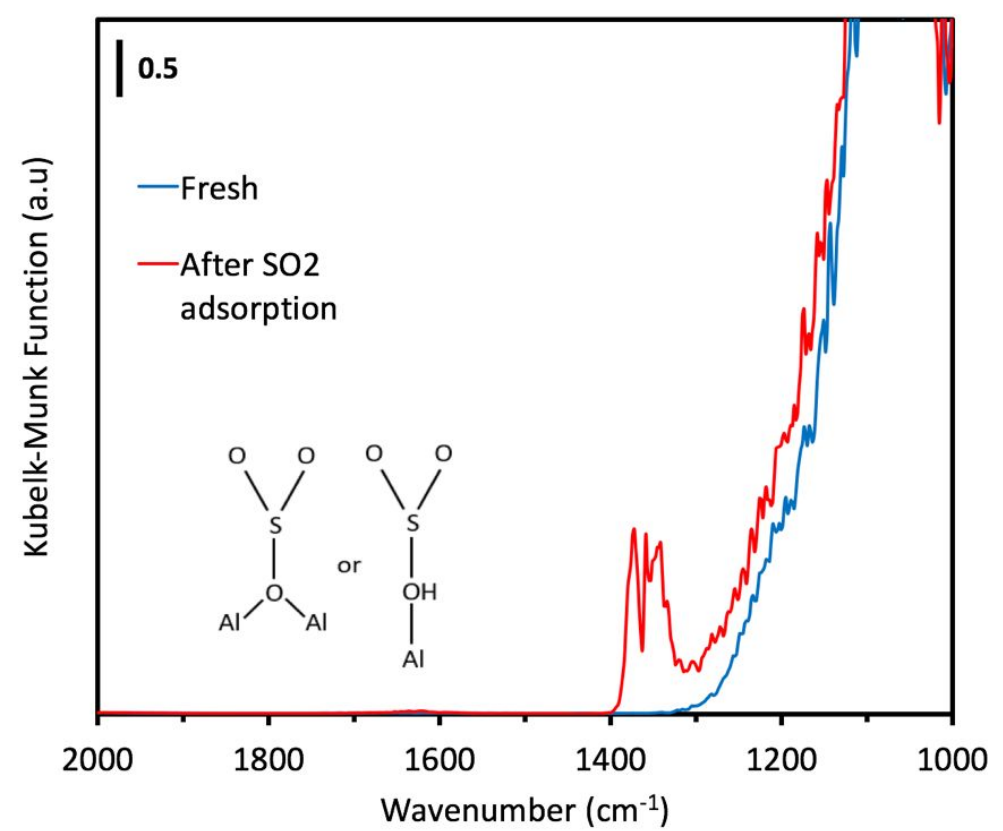

Figure S17: In situ $\mathrm{SO}_{2}$ adsorption over $\gamma-\mathrm{Al}_{2} \mathrm{O}_{3}$ at $150{ }^{\circ} \mathrm{C}$ (no plasma), after subtracting $\mathrm{SO}_{2}$ gas-phase signal. 


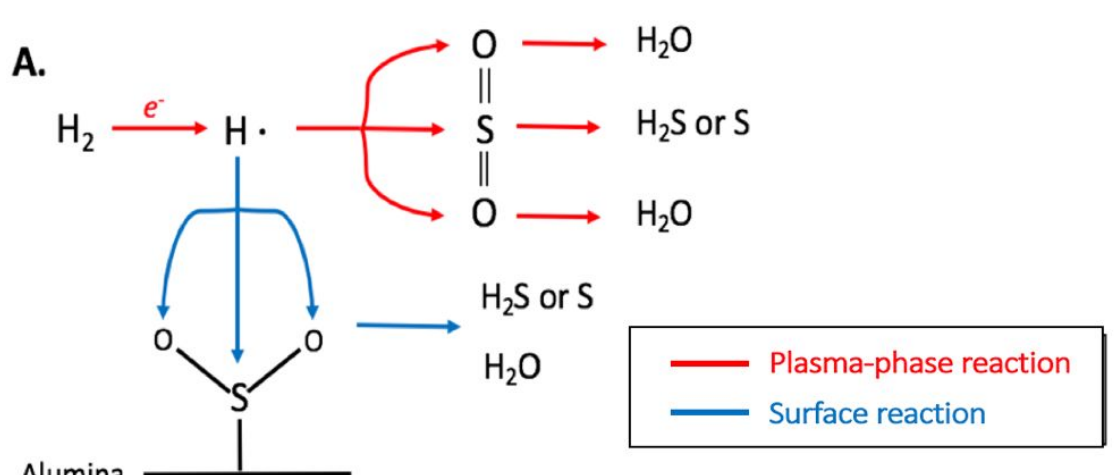

B.

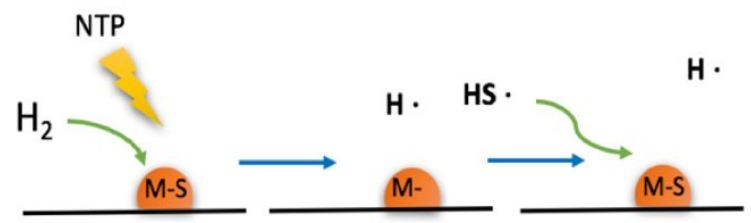

Figure S18: Simplified possible new chemical reactions scheme of $\mathrm{SO}_{2}$ reduction with $\mathrm{H}_{2}$ in plasma catalysis, a. $\mathrm{H}_{2}$ plasma-phase activation, b. $\mathrm{H}_{2}$ catalytic surface activation.

\section{Possible reactions in plasma-catalysis system:}

Table S2: Thermodynamics for $\mathrm{SO}_{2}$ reaction with $\mathrm{H}_{2}$ and $\mathrm{CH}_{4}$.

\begin{tabular}{|c|c|c|c|c|}
\hline & Reaction & $\Delta \mathrm{H}^{0}(\mathrm{~kJ} / \mathrm{mol})$ & $\Delta \mathrm{S}^{0}(\mathrm{~J} / \mathrm{mol} \mathrm{K})$ & $\Delta \mathrm{G}^{0}(\mathrm{~kJ} / \mathrm{mol})$ \\
\hline $\mathrm{S} 1$ & $2 \mathrm{SO}_{2(\mathrm{~g})}+\mathrm{CH}_{4(\mathrm{~g})} \rightarrow 2 \mathrm{~S}_{(\mathrm{l})}+\mathrm{CO}_{2(\mathrm{~g})}+2 \mathrm{H}_{2} \mathrm{O}_{(\mathrm{g})}$ & -205.2 & -17.8 & -200 \\
\hline $\mathrm{S} 2$ & $\mathrm{SO}_{2(\mathrm{~g})}+\mathrm{CH}_{4(\mathrm{~g})} \rightarrow \mathrm{H}_{2} \mathrm{~S}_{(\mathrm{g})}+\mathrm{CO}_{(\mathrm{g})}+\mathrm{H}_{2} \mathrm{O}_{(\mathrm{g})}$ & -1.6 & 157.3 & -48.5 \\
\hline $\mathrm{S} 3$ & $\mathrm{SO}_{2(\mathrm{~g})}+2 \mathrm{H}_{2(\mathrm{~g})} \rightarrow \mathrm{S}_{(\mathrm{l})}+2 \mathrm{H}_{2} \mathrm{O}_{(\mathrm{g})}$ & -184.9 & -94.9 & -156.6 \\
\hline $\mathrm{S} 4$ & $\mathrm{SO}_{2(\mathrm{~g})}+3 \mathrm{H}_{2(\mathrm{~g})} \rightarrow \mathrm{H}_{2} \mathrm{~S}_{(\mathrm{g})}+2 \mathrm{H}_{2} \mathrm{O}_{(\mathrm{g})}$ & -207.4 & -56.6 & -190.5 \\
\hline $\mathrm{S} 5$ & $\mathrm{SO}_{2(\mathrm{~g})}+2 \mathrm{H}_{2} \mathrm{~S}_{(\mathrm{g})} \rightarrow 3 \mathrm{~S}_{(\mathrm{l})}+2 \mathrm{H}_{2} \mathrm{O}_{(\mathrm{g})}$ & -140 & -171.3 & -88.9 \\
\hline $\mathrm{S} 6$ & $\mathrm{H}_{2} \mathrm{~S}_{(\mathrm{g})} \rightarrow \mathrm{S}_{(\mathrm{l})}+\mathrm{H}_{2(\mathrm{~g})}$ & 22.4 & -38.3 & 33.8 \\
\hline
\end{tabular}

Table S3: Possible electron impact reactions

\begin{tabular}{|c|c|c|c|c|}
\hline Species & No. & Reaction & $\begin{array}{c}\text { Required Energy } \\
(\mathrm{eV})\end{array}$ & Ref. \\
\hline $\mathrm{H}_{2}$ & $\mathrm{~S} 1$ & $\mathrm{H}_{2}+e^{-} \rightarrow \mathrm{H}+\mathrm{H}+e^{-}$ & 4.5 & 1 \\
\hline $\mathrm{H}_{2} \mathrm{~S}$ & $\mathrm{~S} 2$ & $\mathrm{H}_{2} \mathrm{~S}+e^{-} \rightarrow \mathrm{HS}+\mathrm{H}+e^{-}$ & 3.93 & 2 \\
\hline \multirow{5}{*}{} & $\mathrm{S} 3$ & $\mathrm{CH}_{4}+e^{-} \rightarrow \mathrm{CH}_{3}+\mathrm{H}+e^{-}$ & 8.8 & 3 \\
\cline { 2 - 5 } & $\mathrm{S} 4$ & $\mathrm{CH}_{4}+e^{-} \rightarrow \mathrm{CH}_{2}+\mathrm{H}_{2}+e^{-}$ & 10 & 4 \\
\cline { 2 - 5 } $\mathrm{CH}_{4}$ & $\mathrm{~S} 5$ & $\mathrm{CH}_{4}+e^{-} \rightarrow \mathrm{CH}+\mathrm{H}_{2}+\mathrm{H}+e^{-}$ & 11 & 4 \\
\cline { 2 - 5 } & $\mathrm{S} 6$ & $\mathrm{CH}_{4}+e^{-} \rightarrow \mathrm{CH}_{4}(v)+e^{-}$ & $0.16-0.36$ & 4 \\
\cline { 2 - 5 } & $\mathrm{S} 7$ & $\mathrm{CH}_{4}+\mathrm{H} \rightarrow \mathrm{CH}_{3}+\mathrm{H}_{2}$ & 0.35 & 3 \\
\hline
\end{tabular}




\begin{tabular}{|c|c|c|c|c|}
\hline \multirow{2}{*}{$\mathrm{C}_{2} \mathrm{H}_{6}$} & $\mathrm{~S} 8$ & $\mathrm{CH}_{3}+\mathrm{CH}_{3} \rightarrow \mathrm{C}_{2} \mathrm{H}_{6}$ & 0 & 3 \\
\cline { 2 - 5 } & $\mathrm{S} 9$ & $\mathrm{C}_{2} \mathrm{H}_{6}+\mathrm{H} \rightarrow \mathrm{C}_{2} \mathrm{H}_{5}+\mathrm{H}_{2}$ & 0.32 & 3 \\
\hline $\mathrm{SO}_{2}$ & $\mathrm{~S} 10$ & $\mathrm{SO}_{2}+e^{-} \rightarrow \mathrm{SO}+\mathrm{O}+e^{-}$ & 10.6 & 5 \\
\hline $\mathrm{N}_{2}$ & $\mathrm{~S} 11$ & $\mathrm{~N}_{2}+e^{-} \rightarrow \mathrm{N}_{2}(A)+e^{-}$ & 6.1 & 6 \\
\hline
\end{tabular}

Where $v$ is the vibrational excited state and $\mathrm{N}_{2}(\mathrm{~A})$ is the first electronically excited state of nitrogen (metastable nitrogen, with lifetime up to $2 \mathrm{~s}$ ).

Table S4: Plasma-surface activation.

\begin{tabular}{|c|c|c|c|}
\hline Species & No. & Reaction & Ref. \\
\hline \multirow{2}{*}{$\mathrm{H}_{2}$} & S1 & $\mathrm{H}_{2}+\square \leftrightarrow \mathrm{H}_{2} \cdot \square$ & - \\
\hline & S2 & $\mathrm{H}_{2} \cdot \boldsymbol{\square}+e^{-} \leftrightarrow \mathrm{H}_{2}{ }^{*} \cdot \boldsymbol{\square}+e^{-}$ & - \\
\hline \multirow{2}{*}{$\mathrm{CH}_{4}$} & S3 & $\mathrm{CH}_{4}+\square \leftrightarrow \mathrm{CH}_{4} \cdot \mathbf{\square}$ & 7 \\
\hline & S4 & $\mathrm{CH}_{4} \cdot \mathbf{\square}+e^{-}+\leftrightarrow \mathrm{CH}_{4}{ }^{*} \cdot \mathbf{\square}+e^{-}$ & 7 \\
\hline \multirow{2}{*}{$\mathrm{SO}_{2}$} & S7 & $\mathrm{SO}_{2}+\square \leftrightarrow \mathrm{SO}_{2} \cdot \mathbf{\square}$ & - \\
\hline & S8 & $\mathrm{SO}_{2} \cdot \boldsymbol{m}+e^{-}+\leftrightarrow \mathrm{SO}_{2}{ }^{*} \cdot \boldsymbol{\square}+e^{-}$ & - \\
\hline
\end{tabular}

Where $\boldsymbol{m}$ is surface adsorption site for $\mathrm{H}_{2}, \mathrm{CH}_{4}$, or $\mathrm{SO}_{2}$.

Table S5: Plasma-phase activation.

\begin{tabular}{|c|c|c|c|}
\hline Species & No. & Reaction & Ref. \\
\hline \multirow{2}{*}{$\mathrm{H}_{2}$} & S1 & $\mathrm{H}_{2}+e^{-} \leftrightarrow \mathrm{H}_{2}{ }^{*}+e^{-}$ & - \\
\hline & $\mathrm{S} 2$ & $\mathrm{H}_{2}{ }^{*}+\square \leftrightarrow \mathrm{H}_{2}{ }^{*} \cdot \square$ & - \\
\hline \multirow{2}{*}{$\mathrm{CH}_{4}$} & S3 & $\mathrm{CH}_{4}+e^{-} \leftrightarrow \mathrm{CH}_{4}{ }^{*}+e^{-}$ & 7 \\
\hline & $\mathrm{S4}$ & $\mathrm{CH}_{4}{ }^{*}+\square \leftrightarrow \mathrm{CH}_{4}^{*} \cdot \boldsymbol{\square}$ & 7 \\
\hline \multirow{2}{*}{$\mathrm{SO}_{2}$} & S7 & $\mathrm{SO}_{2}+e^{-} \leftrightarrow \mathrm{SO}_{2}{ }^{*}+e^{-}$ & - \\
\hline & S8 & $\mathrm{SO}_{2}{ }^{*}+\square \leftrightarrow \mathrm{SO}_{2}{ }^{*} \cdot \mathbf{\square}$ & - \\
\hline
\end{tabular}




\section{Reference:}

1. Sharp, T. Potential-Energy Curves for Molecular Hydrogen and its Ions. Atomic Data 1971, 2, 119-169.

2. Zhao, G.; John, S.; Zhang, J.; Hamann, J. C.; Muknahallipatna, S. S.; Legowski, S.; Ackerman, J. F. Argyle, M. D. Production of hydrogen and sulfur from hydrogen sulfide in a nonthermal-plasma pulsed corona discharge reactor. Chemical Engineering Science 2007, 62, 2216-2227.

3. Wang, L.; Yi, Y.; Wu, C.; Guo, $\mathrm{H} . ; \mathrm{Tu}, \mathrm{X}$. One-Step Reforming of $\mathrm{CO}_{2}$ and $\mathrm{CH}_{4}$ into High-Value Liquid Chemical and Fuels at Room Temperature by Plasma-Driven Catalysis. Angew. Chem., Int. Ed. 2017, 56, 13679-13683.

4. Chung, W.-C.; Chang, M.-B. Review of Catalysis and Plasma Performance on Dry Reforming of $\mathrm{CH} 4$ and Possible Synergistic Effects. Renewable Sustainable Energy Rev. 2016, 62, 13-31.

5. Johnson, C.; Kelly, S.; Parker, J. Fluorescence in the Dissociative Excitation of Sulphur Dioxide by Electron Impact, Journal of the Chemical Society, Faraday Transactions 2: Molecular and Chemical Physics 1987, 83, 985-990.

6. Zhao, G.; Hu, X.; Argyle, M.; Radosz, M. N Atom Radicals and $\mathrm{N}_{2}\left(\mathrm{~A}^{3} \sum \mathrm{u}^{+}\right)$Found to Be Responsible for Nitrogen Oxides Conversion in Nonthermal Nitrogen Plasma, Ind. Eng. Chem. Res. 2004, 43, 5077-5088.

7. Kim, J.; Go, D. B.; Hicks, Synergistic Effects of Plasma-Catalysts Interaction for $\mathrm{CH}_{4}$ Activation. J. C. Phys. Chem. Chem. Phys. 2017, 19, 13010. 